\title{
Political Image as the Substance of the Political Communication in the Era of Post- Politics
}

\section{Tomasz Gackowski, University of Warsaw, Poland}

\begin{abstract}
This paper presents the results of a research project which analyzed the commitments made by prime minister of Poland - Donald Tusk and his government in 2007 and 2008, and compares them with the content of articles published in "Rzeczpospolita" and "Gazeta Wyborcza" (the most opinion-forming newspapers in Poland) during the first 100 days as well as the first year of government. The author confronts two perspectives - classical, Schmittian sense of politics and the new one - post-politics (according to Z. Bauman, S. Žižek and J. Baudrillard). He proposes an aspectual definition of political communication which harmonizes with the idea of the Fourth Estate. Finally author assumes that the key term in the present era of post-politics is an image. What counts are the visions, hopes, dreams, desires, just the image (picture perfect, masking defects, emphazing the benefits), rather than facts, figures, statements and an electoral programmes. This seems to be one of the most important communication barriers in politics - in the present era of post-politics.
\end{abstract}

Keywords: mass media, image, political communication, post-politics, promises, fourth estate 


\section{Introduction}

Edmund Burke (1729-1797) said once: (...) There are Three Estates in Parliament; but, in the Reporters' Gallery yonder, there sat a Fourth Estate more important far than they all. This mature conclusion left a distinctive impression on thinking about the role of the press and later - mass media. What must to be stress out is the fact that when we are pondering the idea of "Fourth Estate" actually we are thinking about a political communication indeed. But what is a present meaning of political communication in the $\mathrm{XXI}^{\text {st }}$ century? To give an answer to this question we have to go back to the roots to the classical meaning of words "political" and "communication".

\section{The Idea of Political Communication - Definition}

Considering the meaning of word "political" make us thinking of Carl Schmitt's "The Concept of Political" (1932). Schmitt argued that "political" - in another words - is the most intense and extreme antagonism. He also admitted that every concrete antagonism becomes that much more political the closer it approaches the most extreme point, that of the friendenemy grouping (Schmitt, 2012: 255).Furthermore he pointed out that political concepts, images, and terms have a polemical meaning. They are focused on a specific conflict and are bound to a concrete situation. It is worth mentioning that - according to Schmittian perspective - in usual domestic polemics the word political is often used interchangeably with party politics. The inevitable lack of objectivity in political decisions, which is only the reflex to suppress the politically inherent friend-enemy antithesis, manifests itself in the regrettable forms and aspects of the scramble for office and the politics of patronage. He pointed out that the demand for depoliticalization which arises in this context means only the rejection of party politics etc. The equation politics $=$ party politics is possible whenever antagonisms among domestic political parties succeed in weakening the all-embracing political unit, the state (Schmitt, 2012: 255). To sum up, "political" in this perspective means "polemical" - the articulation of contradictions.

Leaving aside issues of "politics", it is worth leaningover the meaning of word "communication", which takes its origins from a Latin. On the one hand, you can rely on Latin noun - communitas, communitatis - which means a community, bond and also connectivity, on the other you can count on another noun - communio, communis - which is community property, compliance, or a combination of features in common, the similarity of 
the compounds. The starting point in looking for meaning of this word may be the fourth conjugation verb - communio, communire - which can be translated as the fortification, security, strengthen, encourage or enter into such alliances - communire foedus. Also, the third declension of adjective - communis, commune - can be taken into account because it is explained as: a single, universally accepted, remaining in a relationship, or even social contact. In addition,this key word combined in such a special expressions like - communi consensu - which means with the consent of the general, the general agreement, and also opinio communis - common view, or - in communi - that is for the common benefit, and - in bonum commune - for the common good. We also cannot skip adverbs - communiter and communitus. While the second translates as common, as the former one has a several meanings: together, in general, well, at the same time and for the overall agreement.

Now, when we combine these two words in one term - "political communication" - at first we are starting to think about this phrasing in a processual way. Both words, the first - "political" and the second one - "communication" - famously draws attention to what happens between the main actors of this process - government (political elites), mass media (media staff) and of course society (citizens - voters - recipients of mass media). Each of the actors in political communication has its own interests. However they can realize their aims only in the proper relationship with other actors. We can say that it is some kind of "checks and balances" relationship (according to Montesquieu). They "compete" and cooperate at the same time - of course in a democratic spirit. Otherwise, these interests do not make much sense. The purpose of politics is to communicate effectively with the public through the media and to gain the possible best self-exposure (ideas, programmes, actions and of course image) in the eyes of society - citizens, voters, recipients of mass media. The purpose of the mass media (in the normative perspective (McQuail 1983/2010: 168-189)) is credible mediating in interactions between government and citizens, who, placing them certain expectations, are their recipients, their consumers, and finally clients. The purpose of the society is to be reliably informed about relevant political issues that affect the life of every citizen and to keep a sharp eye on political elites - with the crucial support of the mass media (idea of watchdog - responsible journalism), which have been selected by voters - citizens - recipients of mass media. As we can see, the interests of each of the entities of political communication are dependent on each other and contribute some kind of system of connected vessels, which, even if temporarily, may have divergent interests, butat the end of the day all actors are 
interested in smooth functioning of the entire system. It means effective participation in the dynamic process of investigation to compromise, expose contradictions and blunting things in common in key political issues. According to Schmitt, this is a primary function of the state.

Based on the above findings "political communication" is a process of interaction between political elites, the mass media and the public, whose purpose is to generatea politically relevant content in media coverage, including monitoring, analyzing and commenting on current policies, periodicallyassessingthe government for their campaign promises (and also the later ones) in the name of society - citizens / votersand also forming and expressing the attitude of public opinion to the policy and political elites, which are in power. This definition leads us to the idea of Fourth Estate.

\section{The idea of Fourth Estate - Hypothesis}

Understanding the notion of Fourth Estate (as media used to be named) has been connected with distinguished typology of media power: power as a mediatization, power as an influence, power as a function and last but not least power as a control. First type of power (mediatization) concerns to the essence of media - process of getting to know surrounding world via media by mass audience. From this perspective media become our window on the world and their power consist in creating frames of our perception. Second type of power (influence) is based on an expected relation between media and their recipients. This relation assumes that media with their facts, opinions and entertainment can possible change in some cases mass audience's definite point of view. However we have to bear in mind that this type of media power depends on intentional, not accidental influence of mass media. Third type of power (function) seems to be the most obvious one. Every object which is attributed to a specific function acquire definite power as a part of this function - media system (to inform, to comment, to analyze, to integrate, to entertain, to motivate, to educate, to socialize, to debate, to promote the culture etc.). Finally, fourth type of power concerns to the control idea of media so-called: watchdog. This is a crucial aspect of media power: Media as a great controller of government. On the one hand media should investigate authorities; on the other they should also assess politicians for their campaign pledges. Keeping promises should be and seems to be one of the most important aspects of being a politician. What has to be pointed out is the fact that in most cases - it's a working assumption - citizens voting is based on promises which have been made by politicians during elections. Voters want to believe 
that elected politicians who become a government will keep their promises. Nowadays - in the era of mass media - society seems to put their dreams about political promises redeemed into the media's hands. Media as a Fourth Estate ought to control political elite, judge them for their promises. Willingness to test this - in polish circumstances - was one of the main purposes of the extensive research which some results are presented beneath and which became a base for hypothesis contained in the title of this paper.

\section{Assumptions and Methodology of Research}

The main question of research was: Does polish media - prestige newspapers like a "Gazeta Wyborcza" and "Rzeczpospolita" - play a role of Fourth Estate in the process of political communication in Poland which means assessing government for their pledges? In this research I have checked quantitatively and qualitatively what parties (Platforma Obywatelska (ang. Civic Platform (PO)) and Polskie Stronnictwo Ludowe (ang. the Polish Peasants' Party (PSL)) and later Donald Tusk's government) have promised in electoral campaign in 2007 and straight after elections (during creating a government - October and November of 2007). Then I have analyzed content of polish newspaper in a time of one hundred days and a year after a swearing-in ceremony of Donald Tusk's government (February-March and September-October of 2008). In this time polish newspaper are judging polish government in special way (some kind of political / media ritual - see: Rothenbuhler 1998:78-89, 96-106). There is a belief that if government will not put the planned reforms into practice in a first one hundred days or as a last in a first year of govern, it is much more probable that government will not carry these reforms out till the end of their term. That's why media attached great significance to the mentioned periods in which they try to sum up achievements of the government. (Every article in which one of this phrasings appeared "one hundred days", "three months" or "a year", "twelve months" - was taken to the sample (One hundred days - "Rzeczpospolita" - 98 articles, "Gazeta Wyborcza" - 95 articles; A year after Donald Tusk's government was constituted - "Rzeczpospolita" - 67 articles, "Gazeta Wyborcza" - 48 articles)).

In the 2007 election campaign, politicians made numerous pledges. The winning parties Civic Platform (PO) and the Polish Peasants' Party (PSL) - by publishing their party platforms on the Internet, made meaningful commitments. In this research I haveassumed that in a democracy, society can rely on the media to execute political commitment - especially 
with acclaimed journalists from daily newspapers "Rzeczpospolita" or "Gazeta Wyborcza". The political opposition is in this case less reliable (own, political interests). It is the duty of journalist to account politicians of their campaigns and pledges for the purpose of fulfilling reader/viewer expectations.

To find out how "Rzeczpospolita" and "Gazeta Wyborcza" account politicians of their pledges, it was established, what kind of pledges PO and PSL made. Party platforms were subject to a quantitative and qualitative analysis. An extensive worksheet was created in MS Excel 2007 with all PO and PSL pledges made in campaign documents. These were then compared with pledges made by Donald Tusk, the head of the PO-PSL government, in his parliamentary exposé after swearing in the government by late president Lech Kaczyński. For the purpose of this research terms (operational definitions) were created, which in the belief of the author, made it possible to organize the analysis.

Due to the nature of making promises by politicians to voters, three types of pledges were distinguished. These were normatives, pledges made in party platforms, declarations and in the exposé; declaratives, which are commitments from press statements and interviews made by politicians, and lastly, speculatives or expectives, a promise, which journalists assumed politicians made or should have made. Referring to the above distinction, an analysis of pledges made by PO and PSL was conducted, based on party platforms ${ }^{\mathrm{i}}$ and daily newspapers "Rzeczpospolita” and "Gazeta Wyborcza” from November and December 2007.

The exposé of Prime Minister Donald Tusk from November $23^{\text {rd }} 2007$ was analyzed in the same way - the number of pledges made. It should be stated that a pledge was defined as every possible to independently distinguish, outside the sentence in which it occurs, postulated change or maintenance of status quo expressed in a volitional manner. One sentence could contain more than one pledge, in which case each was counted separately. For example, six pledges were stated in the demonstration sentence from PO's program: "Rationalizing the program »Study in Poland« and stationing the European Institute of Innovation and Technology in Wroclaw, promoting the careers and academic promotion of young scholars through a better scholarship system and increasing international mobility, introducing financial rules in selected prioritized research projects". 
Promises often had a tendency to overlap. More than once they concerned the same issue, although presenting another aspect of it. For example, the promise of a "cheaper state" is connected with the promise to "decrease bureaucracy", and this in turn relates to the promise of "simplifying the legal system and improving its inner cohesion and transparency". Despite such tendencies, each of these promises was treated separately because establishing boarders between pledges and determining which is included in which would interfere too much with the intentions of the speaker. Especially since there is a premise in formulating a promises in a certain way. Pledges that were repeated were not counted additionally; however, their repetition was marked as having a higher exposition than in the case of others, which were mentioned just once.

\section{Results of Research}

The research found that in the chosen sources and dates, the Donald Tusk's government made 647 pledges. If we were to sum the total number of pledges accounted (336) and redeemed (246) in both "Rz" and "GW" after 100 days and the $1^{\text {st }}$ year of the government, and divide it in half, as $50 \%$ of the accounts, to a different degree, overlapped and not every redeemed pledge was such par excellence and others were in both dailies, all in all, the newspapers redeemed the government in 291 cases.

Table 1. Pledges, their account and redeeming - PO-PSL coalition government (2007-2008) in "Rzeczpospolita" and "Gazeta Wyborcza"

\begin{tabular}{|l|c|c|c|}
\hline & Pledges & Accounts of pledges & Redeemed pledges \\
\hline $\begin{array}{l}\text { Fall 2007 } \\
(\mathrm{N}, \mathrm{D}, \mathrm{SvE}) *\end{array}$ & 548 & - & - \\
\hline "100 days" & 34 & 147 & 99 \\
\hline $1^{\text {st }}$ year in government & 65 & 189 & 147 \\
\hline Total & $\mathbf{6 4 7}$ & $\mathbf{3 3 6}$ & $\mathbf{2 4 6}$ \\
\hline
\end{tabular}

* Sum of normatives, declaratives, speculatives vel expectants.

Source: Own research. 


\section{Conclusions}

The results of research give something to think about. Namely, if newspaper looks favorably on Donald Tusk's government, journalists of this daily assess him for his pledges to a smaller degree and vice versa. In this research "Gazeta Wyborcza" was much more inclined towards PO-PSL's government, while "Rzeczpospolita" seems to be much more hard on ministers in Donald Tusk's government. Furthermore, leaving aside political sympathies, research proved a great difference in the discourse of these two newspapers reviewing after all the same government in the same time. It is not about opinions which are and should be different. It's about facts. Strictly speaking, what "Gazeta Wyborcza" regards as a keeping a campaign promise, "Rzeczpospolita" considers just the opposite, as a breaking a pledge or failing to keep a promise. When "Gazeta Wyborcza" used a word "already" describing definite reforms of Tusk's government, "Rzeczpospolita" used a word "just". What must to be pointed out is fact that "Wyborcza" very often wrote about different promises than "Rzeczpospolita". Donald Tusk's government was also praised and criticized for different actions by analyzed newspapers. This alarming conclusions show polishes political communication in a bad light. As it turned out polish discourse of prestige newspaper seems to be very deeply divided. That's why Wyborcza's reader will have serious problems with reaching an agreement with Rzeczposplita's reader - in opinions and facts about polish political communication and effectiveness of a current government.

To sum up, this researchseems to reveal some of dysfunctions of polish political communication. After all the most opinion-forming newspapers in Poland seem to assess politicians for their promises, but they do it in a different way and various scale (problem of political sympathies and bias journalism), whereas numbers of promises - what was proved quantitatively - made by politicians during a campaign and straight after increase in every next day of govern. Politicians are fond of permanent talking about future and what "will" be, not what is now, what was carried out, how many promises were redeemed. They just simply prefer to make a new promises (changing, narrowing or widening elder one's) over and over again.

\section{Discussion - Toward Post-Politics}

With results like this, other research questions arise: why did the media account the government of only $45 \%$ of the issues they promised to manage? Is that a lot or a little? 
Media cannot write about everything as they are restricted by the place and time of working on journalistic material, however, through this explanation, we assume they prioritize and chose the most important issues, convinced they are doing it for the benefit of society. Other questions which should be posed concern the number of pledges made - why do politicians promise so much if the media account them of only the most important ones? These concerns may indicate that the presented study, which was based on normative, structuralist and functionalist perspective (Lewellen, 2003; See also: Imbeau et al., 2009andPétryet al., 2009:65-82) seems to be not adequate to present politics?

From Schmittian perspective promises - which were the main topic of research - are a part of a social contract with voters, who believe that this particular political platform, this politician, after winning the elections, will keep his word. However, one has to be aware that an equally important, if not prevailing altogether, factor influencing political decisions, is an image itself, understood in terms of marketing. Perhaps here lies the answer to allegations on naively believing that voters are familiar with party programmes or promises, never intended to be kept in the first place.

Zygmunt Bauman has noticed that - nowadays - we live in the "casino culture" which instantaneous and episodic announce the end of "our well known politics" (Bauman, 2008:193). We could say - an Schmittian politics. Bauman convinces that we are living in the era of fast foods - quick thinking and quick talking. Times of long, four hours Lincoln's speeches are gone forever. Today politicians need to think and talk with fast, witty catchphrases which draw impatient attention of television. Slavoj Žižekput it straight:"Postpolitics thus emphasizes the need to leave old ideological visions behind and confront new issues, armed with the necessary expert knowledge and free deliberation that takes people's concrete needs and demands into account" (Žižek, 1999a:198). He underlines that postpolitics is not a conflict between the great ideological visions materialized by various parties, but the collaboration of enlightened technocrats (economists, public opinion specialists, etc.) and liberal multiculturalists. The purpose is to gain a compromise - more or less universal(Žižek, 1999b).

Bauman has remarked that Wladimir Putin and Tony Blair (representatives of the new era era of post-politics) wisely avoided in their campaigns lecturing political programmes and 
conceptions (Bauman, 2008:193). In the name of building attractive image in exchange for demanding, difficult to understand ideas of ruling and sense of their philosophy of power (ideology). Simon Hoggart from "Guardian" - describing the main criterion of post-politics wrote once (Hoggart, 2000):

"Tony Blair gave an important talk to the newspaper conference yesterday. Not for the first time, I was struck by the way a Blair speech is closer to a musical composition than to mere rhetoric. Like a piece of music, its aim isn't to inform but to create good feelings. It's no more about facts and policies than the Pastoral Symphony is an examination of the common agricultural policy.(...) Nobody ever finished listening to a Blair speech and said, "well, I learned something there". Instead they praise the bravura performance and enjoy the afterglow created by the mood".

Today political marketing is, in a sense of post-politics, a part of so called "the democratic performance", which indirectly justifies and legitimizes policy model in which images media representations - are more important than the content of political programmes, making a promises by political elites or political visions and ideas of changing anything. It seems to be that the present world is not inhabited anymore by homo seriosus, the man who embodies the idea of discovering the truth, not afraid of conflict and struggle, tied to his identity, family, country and place. The new world - world of post-politics - is a place where the truth is not a fundamental value, there reigns homo rhetoricus for whom discovering the reality is connected with trying to manipulate it, create it. The truth isn't timelessness and incontrovertible. The truth is what has been recognized as it (Kusiak, 2011:173).

Next to Wladimir Putin and Tony Blair, often described as a glaring example of the end of the Schmittian politics/ideology is Silvio Berlusconi. His political program seems to be structured like a TV programming - everyone will find something interesting. Such politicians as he is will be the main beneficiaries of the end-time of great ideologies. In the era of post-politics the main substance of political communication is an image - media representation. In other words - the expression and impression. This perspective show in facthow"new politicians" can easily promise people anything without even wishing to implement these commitments. 
The author of this article - in presented research - assumed that voter decisions are rational and certain politicians chosen because their diagnose of Poland's problems and the proposed remedies (election promises) seem justified, pragmatic and efficient. If that were not the case, it would mean voters are guided by feelings or impressions on the party image and its leaders. The question is not what really is, but how it is perceived. It ennobles the media and makes them "rulers of the mind" - as a result of civic apathy (Blumler and Gurevitch, 1995).

If the above diagnose is a true, then hopes connected with the quality of public debate, its substantiality, should be sought in media and journalists, who through their texts will convince voters that promises are made to be kept, campaign programmes written to be implemented, and political parties accounted for their actions. This is indeed the charm and potential of media studies. Bernard Marqueritte was right bringing up the diagnose of Jack Fuller, who believes that the fate of media is strictly connected with the world of politics: "Where media are weak, don't have the trust of society or just don't give honest, in-depth information allowing individual judgment, people quickly lose interest in public life, stop thinking about the common good and stop voting"(Fuller, 1996/1997, cited by Marqueritte, 2009:253). Bauman admitted that:

"If the orthodox authorities are still around they need to compete with celebrities in the limelight on terms which seldom work in their favour, and certainly strip them of the privilege they once enjoyed. The humdrum, dull and altogether unspectacular business of traditional politics is ill fit to strike the eye among the crowd of competitors, and if it succeeds, it won't be likely to attract many watchers, let alone hold their attention for as long as it takes to see the business through. TV quizzes daily reiterate the message that the date of the third wedding of a pop star or a footballer's scoring a hat trick count for as much as who won the last war or the year in which women gained electoral rights" (Bauman, 2008:193)

As Davis Merritt pointed out, such a situation results directly from the quality of journalism: 
"It is not a coincidence that the fall of journalism and the fall of public life are taking place at the same time. In modern society, they are interconnected: Public life needs the information and perspective that journalism can provide, and journalism needs a viable public life, because without [the latter] there is no need for journalism" (Merrit, 1995, cited in Marqueritte, 2009:253).

Furthermore Bauman has noticed in a great way a distance between Schmittian politics and post-politics - between authority and idolatry (in a background there is always a key role of mass media - the creator of images of present politicians):

"Politics with a capital ' $\mathrm{P}$ ' needs leaders with authority. Life politics, on the other hand, needs idols. The difference between the two cannot be greater, even as some leaders happen to be idolized while idols sometimes claim authority by pointing out the massiveness of their worship. Politics is many things, but it would hardly be any of them were it not the art of translating individual problems into public issues, and common interests into individual rights and duties. Leaders are experts in such translation (...)" (Bauman, 2008:201)

In a similar way wrote Jean Baudrillard, theadherent of the idea of the post-politics:

"(...) We are still in the same boat: no society knows how to mourn the real, power, the social itself, which is implicated in the same loss. And it is through an artificial revitalization of all this that we try to escape this fact. This situation will no doubt end up giving rise to socialism. Through an unforeseen turn of events and via an irony that is no longer that of history, it is from the death of the social that socialism will emerge, as it is from the death of God that religions emerge. A twisted advent, a perverse event, an unintelligible reversion to the logic of reason. As is the fact that power is in essence no longer present except to conceal that there is no more power. A simulation that can last indefinitely, because, as distinct from "true" power - which is, or was, a structure, a strategy, a relation of force, a stake - it is nothing but the object of a social demand, and thus as the object of the law of supply and demand, it 
is no longer subject to violence and death. Completely purged of a political dimension, it, like any other commodity, is dependent on mass production and consumption. Its spark has disappeared, only the fiction of a political universe remains (...)" (Baudrillard, 2005:37).

What must to be stress out is the fact that at the moment we are dealing with a sort of a media legitimization of power - a new type of legitimacy - due to expansion of electronic media (mainly TV). It depends primarily on the attractiveness of a media image, the skillful presence in the mass media, the specific characteristics considered as a media attractive and efficient which is connected with extra abilities to express yourself effectively in front of the lens and microphones of the mass media.In the Schmittan era of politics the most important were political issues, today - in the era of post-politics - the most important seems to be a symbolic issues. There is no politics in $\mathrm{XXI}^{\text {st }}$ century without mass media. If somebody is not present in mass media, heis condemned to a political non-existence - so called "social annihilation" (Skarżyńska, 2005:315). In another word: this is important, what is said in the mass media.

In this context it is worth reminding a well-known rule of marketing. Namely, "person is a message" (Seitel, 2003:172-173). It means that nothing but person of politician (his image, impression) has a bigger impact than what he has got to pass (ideas, ideology, beliefs and of course also pledges). It is said that television programmes saturated with an affection caused an agitation, a sort of a physiological processes, analogous to the processes which are accompanying experience of emotion in the natural conditions of life. It turns out that the media presentation (image) of politician is the main and the most effective means of presenting themselves to the audience (recipients - citizens - voters) (Skarżyńska, 2005:321). Fraser P. Seitel already draw attention to - announcing somehow present times - "era of postpolitics" - the criterion of liking. It is not about the political programmes. It is not about the ideology. It is also not about political pledges and keeping promises (Seitel, 2003:173). It is about image and impression - a great impact on the audience of political spectacle. Here we are reaching an idea of politicotainment (criterions of infotainment adapt to politics (Dörner, 2001; Riegert et al., 2007)). In present we are even talking about somewhat of television's leadership or better - television's primacy. TV is not (is not able?) fulfilling the idea of watchdog - assessing politicians from their pledges (lack of time, request of dynamism, 
pressure of entertainment - tabloidization etc.). TV is not controlling politicians. It is just the opposite - TV is authorizing politicians in the awareness of public opinion (Sajna, 2006). Not by what they say, but by how they look, how they present themselves, in that they are simply appearing.

Jean Baudrillard - many years ago - has described this condition in the following manner:

"Even though the political has long been the agent of nothing but spectacle on the screen of private life. Digested as a form of entertainment, half-sports, half-games (see the winning ticket in American elections, or election evenings on radio or TV); like those old comedies of manners, at once both fascinating and ludicrous. For some time now, the electoral game has been akin to TV game shows in the consciousness of the people. The latter, who have always served as alibi and as supernumerary on the political stage, avenge themselves by treating as a theatrical performance the political scene and its actors. The people have become a public. It is the football match or film or cartoon which serves as models for their perception of the political sphere their own opinions in the daily opinion polls. Nothing in all this engages any responsibility. At no time are the masses politically or historically engaged in a conscious manner (...)" (Baudrillard, 1983:37-38).

To sum up, it must to be pointed out that in the era of post-politics politicians don't want to be outstanding. They don't want and they aren't statesmen. They simply don't have to. It is not a proper criterion in present days. This Schmittian perspective is gone. Followers of postpolitics admit that we are living in times when ideological conflicts and differences are ended. That is what counts now is the image and the ability to effective administrating, not governing, but managing. Politicians want to be liked. They want to be like buddies of their voters, as closer them as it is possible - via mass media. It seems to be that a great part of the electorate of present political parties is guided by feelings or impressions on the party image and its leaders. It would then mean a triumph of package over content, handshake and smile over substantial discussions, illusion over reality. Perhaps this is the core of modern (postmodern) political communication (post-politics), which has begun to function as a comedy series and soap operas. What counts are visions, hope, dreams, aspirations, image (perfectly 
masking the faults and showing-off successes), not facts, numbers or accomplished and accounted campaign programs? In which case, political reality would have been substituted by the media world of politics (it is worth reminding the idea of mediatization of politics (Mazzoleni and Schulz, 1999; Schulz, 2004; Strömbäck, 2008) and of course the idea of politicization of media (colonization of media by politics (Meyer, 2001; Hallin et al., 2002; Street, 2005). This seems to be one of the most important aspect of communication barrier in politics - in the present era of post-politics. 


\section{References:}

Baudrillard, J. (2005), Symulakry i symulacja, Warsaw: SiC! 2005; In French - first edition: Baudrillard, J. (1981), Simulacres et simulation, Paris: Galilee; See in English: Baudrillard, J. (1994), Simulacra and simulation, Michigan: University of Michigan Press;

Baudrillard, J. (1983), In the Shadow of the Silent Majorities ... or the End of the Social and Other Essays, New York: Semiotext(e); In French - first edition: Baudrillard, J. (1978), Á l'ombre des majorités silencieuses ou la fin du social, Paris: Bibliothèque Médiations;

Bauman, Z. (2008), Świat z telewizja, świat w telewizji, [in:] Halawa, M. , Wróbel, P., (eds.), Bauman o popkulturze. Wypisy, Warsaw: WAiP, p. 177-181; See in English - first edition: Bauman, Z. (2002), Society Under Siege, Cambridge: Polity Press;

Blumler J., Gurevitch M., (1995), The Crisis of Public Communication, London: Routledge;

Dörner, A. (2001), Politainment: Politik in der medialen Erlebnisgesellschaft, Frankfurt: Fischer;

Fuller, J. (1996/1997), News Values. Ideas for an information age, Chicago: The University of Chicago Press;

Hallin, D., Papathanassopoulos, S. (2002), "Political Clientelism and the Media: Southern Europe and Latin America in Comparative Perspective", Media, Culture and Society, 24/2, pp. 175-195;

Hoggart, S. (2000), Beethoven Blair punds kettle drums for Britain, "Guardian", 29 March 2000, p. 2 - http://www.guardian.co.uk/uk/2000/mar/29/guardiancolumnists - access: 23.03.2013;

Imbeau,L.M. (2009), (ed.), Do They Walk like They Talk? Speech and Action and Policy Processes, New York - London: Springer Science + Business Media;

Kusiak, P. (2011),"Postpolityka. W poszukiwaniu istoty zjawiska", Colloquium Wydziału Nauk Humanistycznych i Społecznych Akademii Marynarki Wojennej,III, pp. 157-180 [http://www.publikacjeonline.wnhis.iq.pl/numery/III/PK.pdf - Access: 23.03.2013];

Lewellen, T. C. (2003), Political Anthropology: An Introduction, Santa Barbara: Preager Publishers;

Marqueritte, B. (2009),"W poszukiwaniu misji mediów", [in:] M. Bonikowska (ed.), Media a wyzwania XXI wieku, Warsaw: TRIO, pp. 246-262; 
Mazzoleni, G., Schulz, W. (1999). "Mediatization" of Politics: A Challenge for Democracy?", Political Communication, 16(3), pp. 247-261;

McQuail, D. (1983/2010), McQuail's Mass Communication Theory, $6^{\text {th }}$ edition, LondonThousand Oaks-New Delhi-Singapure: Sage Publications;

Merritt, D. (1995), Public Journalism and Public Life. Why Telling the News isn't Enough, Mahwah-New Jersey: Lawrence Erlbaum Associates;

Meyer, T. (2001), Mediokratie. Die Kolonisierung der Politik durch die Medien, Frankfurt: Suhrkamp Verlag;

Pétry, F., Collette, B. (2009), "Measuring How Political Parties Keep Their Promises. A Positive Perspective from Political Science", [in:] Imbeau,L.M., (ed.) Do They Walk like They Talk? Speech and Action and Policy Processes, New York - London: Springer Science + Business Media, pp. 65-82;

Riegert, K. (2007), (ed.), Politicotainment. Television's Take on the Real, New York: Peter Lang Publishing;

Rohtenbuhler, E.W. (1998), Ritual Communication: From Everyday Conversation to Mediated Ceremony, London: Sage Publications;

Sajna, R (2006), "Berlusconi, Putin, Chaves - trzy modele przywództwa telewizyjnego", [in:] Piasecki, A. K. (ed.),Modele przywództwa. Wymiar lokalny, krajowy, międzynarodowy, Cracow: Profesja,pp. 316-328.

Schmitt C. (2012), Pojęcie polityczności, [in:] Teologia polityczna i inne pisma, Warsa: Aletheia, pp. 245-314. See in English: Schmitt, C. (1996), The Concept of Political, Chicago: University of Chicago Press; See in German - first edition: Schmitt, C. (1932/1963), Der Begriff des Politischen, Muenchen: Duncker \& Humblot [http://will.rewi.huberlin.de/files/WS\%202012\%2013/VL\%20SP\%202\%20201213/Der\%20Begriff\%20d es\%20Politischen.pdf - access: 23.03.2013].

Seitel, F. P. (2003), Public relations w praktyce, Warsaw: Felberg SJA, In English - first edition: Seitel, F. P. (1980/2000), The Practice in Public relations, $8^{\text {th }}$ edition, Prentice Hall: Pearson Eduaction (available $11^{\text {th }}$ edition - 2010);

Schulz, W. (2004), "Reconstructing Mediatization as an Analytical Concept", European Journal of Communication, 19/1, pp. 87-101;

Street J., (2005), "Politics Lost, Politics Transformed, Politics Colonised? Theories of the Impact of Mass Media", Political Studies Review, 3, pp. 17-33; 
Strömbäck, J., (2008), "Four Phases of Mediatization: An Analysis of the Mediatization of Politics", International Journal of Press/Politics, 13, pp. 228-246.

Skarżyńska, K. (2005), Człowiek a polityka. Zarys psychologii politycznej, Warszawa: Scholar;

Žižek, S. (1999a), The Ticklish Subject - The Absent Centre of Political Ontology, London: Verso;

Žižek S., (1999b), Carl Schmitt in the Age of Post-Politics, [in:] Mouffed, Ch. (ed.), The challenge of Carl Schmitt, London - New York: Verso,pp. 18-38. 